\title{
Analisis Efektivitas Dan Efisiensi Tata Kelola Tempat Pelelangan Ikan Dalam Mendukung Sistem Logistik Ikan Di Kota Makassar (Studi Kasus Ppi Paotere Kota Makassar)
}

\section{Performance Analysis of Fish Auction Place on Efficiency and Effectiveness of Fish Logistic System in Makassar City}

\author{
Andi Adri Arief $^{1 凶}$, Harnita Agusanty $^{2}$, Kasri, Muh. Dalvi Mustafa \\ ${ }^{1}$ Departemen Perikanan, FIKP, Universitas Hasanuddin \\ Jln. Perintis Kemerdekaan Km 10, Makassar, 90245 \\ ${ }^{2}$ Balai Budidaya Air Payau, Kementerian Kelautan dan Perikanan Republik IndonesiaTakalar, Sulawesi Selatan \\ corresponding author: andi_adriunhas@yahoo.com
}

\begin{abstract}
Abstrak
Penelitian ini bertujuan untuk menganalisis tingkat kepuasan pengguna pelelangan serta kinerja pengelolaan TPI yang mendukung efektivitas dan efisisensi system logistic ikan nasional di Sulawesi Selatan dengan mengambil kasus di PPI Paotere Kota Makassar. Metode yang digunakan adalah studi kasus. Analisis data menggunakan analisis deskriptif. Kepuasan pengguna pelelangan menggunakan analisis Importance and Performance Analysis (IPA), sementara ukuran kinerja pengelolaan TPI dari segi ekonomi dan efisiensi menggunakan analisis value for money. Hasil penelitian menunjukkan bahwa kepuasan pengguna pelelangan masih berada di bawah kriteria puas. Kepuasan pedagang berada pada kriteria cukup puas. Untuk Kinerja tempat pelelangan ikan di PPI Paotere secara keseluruhan dinilai cukup ekonomis dari segi input dengan capaian nilai kinerja input sebesar $86 \%$, sedangkan kinerja pengelolaan TPI dinilai tidak efisien dengan nilai kinerja 123\% sehingga sangat mempengaruhi kinerja komponen distribusi dalam sistim logistic ikan. Integrasi dari empat komponen SLIN di PPI Paotere yaitu; pengadaan, penyimpanan, trasportasi dan distribusi belum berada dalam tata kelola integrative yang efisien dalam satu system sehingga mekanisme tata kelola sisteim logistic yang terjadi tidak saling mendukung satu sama lain.

Kata kunci : Tata kelola, kinerja, TPI, sistem logistik, perikanan
\end{abstract}

\begin{abstract}
This study aims to analyze the level of user satisfaction and performance of fish auction place management that supports the effectiveness and efficiency of national fish logistics system in south sulawesi by taking the case in paotere fish auction place makassar city. The method used is case study. Data analysis using descriptive analysis. Auction satisfaction using analysis of importance and performance analysis (ipa), while measures of fish auction place management performance in terms of economy and efficiency using value for money analysis. The results of research showed that satisfaction user of the auction is still under satisfied criteria. The satisfaction of traders is on the quite satisfied criteria. The performance of fish auction place in paotere fish auction place as a whole is considered to be quite economical in terms of inputs with performance input value of $86 \%$, while the performance of fish auction place management is considered inefficient with a performance value of $123 \%$, which greatly affects the performance of distribution components in the fish logistic system. The integration of four components of national fish logistic system in paotere fish auction place namely; procurement, storage, transportation and distribution have not been in one system of efficient integrative governance so that logistic system governance mechanism happened do not support each other.
\end{abstract}

Keywords: governance, performance, fish auction place, logistics system, fisheries

\section{Pendahuluan}

Gagasan model pengembangan SLIN dengan tata kelola yang efektif dan efisien di tingkat daerah (provinsi dan kabupaten/kota) diharapkan mampu mendorong optimalisasi 
produksi dan distribusi hasil perikanan yang dapat menghubungkan antara daerah produsen dan daerah konsumen, menopang ketahanan pangan nasional serta mensejahterakan nelayan. Sistim logistik ikan itu sendiri merupakan sistem manajemen rantai pasokan ikan dan produk perikanan, bahan dan alat produksi, serta informasi mulai dari pengadaan, penyimpanan, sampai dengan distribusi, sebagai suatu kesatuan dari kebijakan untuk meningkatkan kapasitas dan stabilisasi sistem produksi perikanan hulu-hilir, pengendalian disparitas harga yang akan melahirkan jaminan ketersediaan, keterjangkauan, dan keberlanjutan untuk pemenuhan konsumsi ikan dan industri pengolahan ikan.

Kaitan dengan itu, pelabuhan perikanan merupakan star point yang penting dan harus mendapat penanganan yang serius bagi efektivitas dan efisiensi system logistic ikan nasional, mulai dari pendaratan, pembongkaran sampai dengan pemasaran. Aktivitas ini terjadi hampir di semua tipe pelabuhan baik skala besar yaitu Pelabuhan Perikanan Samudera (PPS) sampai dengan tipe pelabuhan skala kecil yaitu Pangkalan Pendaratan Ikan (PPI).

Sebagai wilayah studi kasus, PPI Paotere merupakan pelabuhan perikanan yang sarat dengan aktivitas pendaratan sampai pada aktivitas pemasaran. Data laporan tahunan 2014 menunjukkan bahwa jumlah produksi yang didaratkan di PPI Paotere sebesar 7.393.000 Kg. Hal ini menjadikan PPI Paotere sebagai salah satu pelabuhan perikanan yang memberikan konstribusi signifikan dalam system logistic ikan nasional.

Dengan demikian, efektivitas dan efisiensi dari mekanisme untuk menciptakan keteraturan dan kelancaran dalam traksaksi yang terjadi di TPI serta supporting dari infrastruktur utama dan penunjang menjadi tolak ukur akan kinerja PPI dalam menunjang sistim logistic ikan baik secara local, regional, nasional dan internasional. Penelitian ini bertujuan untuk mengukur kinerja pengelolaan tempat pelelangan ikan (TPI) Paotere terhadap efisiensi tata kelola dengan menggunakan pengukuran kinerja dan konsep Value for Money.

\section{Metode Penelitian}

Metode yang digunakan untuk mencapai tujuan penelitian melalui deep interview, pengamatan (observation),penggunaan kuisioner, focus group disscusion (FGD) serta participatory Rural Appraisal (PRA) dengan stakeholder dan Kajian Pustaka (literature review). Analisis data menggunakan pendekatan analisis deskriptif kualitatif dan kuantitatif. Kepuasan pengguna pelelangan menggunakan analisis Importance and Performance Analysis (IPA), sementara ukuran kinerja pengelolaan TPI dari segi ekonomi dan efisiensi menggunakan analisis value for money (Mahmudi, 2010). 
Kepuasan pengguna pelelangan diukur dengan menggunakan metode Importance and Performance Analysis. Metode ini merupakan penentuan tingkat kepuasan yang dilakukan berdasarkan atribut-atribut pelayanan yang diberikan. Penilaian kepentingan dan kepuasan pengguna pelelangan dilakukan dengan menggunakan diagram kartesius tingkat kinerja dan kepentingan dari atribut-atribut kepuasan pengguna pelelangan. Masing-masing atribut akan menempati salah satu kuadran yang terdapat dalam diagram berdasarkan rata-rata skor kinerja (RSK) dan rata-rata skor kepentingan (RSP) yang dimilikinya. Pengukuran tingkat kepuasan pengguna pelelangan dalam penelitian ini terbagi menjadi dua yaitu, kepuasan nelayan dan kepuasan pedagang.

\section{Hasil dan Pembahasan}

Pengukuran kinerja pengelolaan tempat pengelolaan ikan di PPI Paotere

\section{Kepuasan nelayan}

Secara kuatifikasi gambaaran Nilai RSK dan RSP menurut nelayan tergambarkan pada Tabel 1.

Tabel 1. Penilaian kinerja dan kepentingan nelayan

\begin{tabular}{|c|c|c|c|c|c|}
\hline Dimensi & No. & & RSK & RSP & Gap \\
\hline \multirow{16}{*}{ Fasilitas TPI } & 1 & Kebersihan fasilitas TPI & 2,8 & 4,4 & $-1,6$ \\
\hline & 2 & Perbaikan fasilitas TPI & 3,8 & 4,2 & $-0,4$ \\
\hline & 3 & Kemudahan dalam penggunaan fasilitas & 3,4 & 3,8 & $-0,4$ \\
\hline & 4 & Basket & 3,6 & 4,2 & $-0,6$ \\
\hline & 5 & Alat timbangan & 3,4 & 3,8 & $-0,4$ \\
\hline & 6 & Gedung TPI & 3,4 & 4 & $-0,6$ \\
\hline & 7 & Penyediaan air bersih & 2,6 & 4 & $-1,4$ \\
\hline & 8 & Tempat cuci tangandan toilet & 3 & 4 & -1 \\
\hline & 9 & Cold Storage & 2,2 & 4 & $-1,8$ \\
\hline & 10 & Luas Area TPI & 3,6 & 4 & $-0,4$ \\
\hline & 11 & Keadaan Kantor Administrasi & 3 & 3,8 & $-0,8$ \\
\hline & 12 & Penyediaan Es & 4,2 & 4,4 & $-0,2$ \\
\hline & 13 & Penyediaan BBM/Solar & 4,8 & 4,2 & 0,6 \\
\hline & 14 & Akses Masuk ke TPI & 3 & 4,4 & $-1,4$ \\
\hline & 15 & Ketersediaan Lahan Parkir & 4 & 4 & 0 \\
\hline & 16 & Panjang Dermaga & 4,6 & 4,4 & 0,2 \\
\hline \multirow{6}{*}{ Aktivitas Pelelangan } & 17 & Ketepatan waktu pelaksanaan lelang & 3,8 & 4,2 & $-0,4$ \\
\hline & 18 & Kemudahan dalam pembayaran & 3,8 & 4 & $-0,2$ \\
\hline & 19 & Administrasi di TPI & 3,6 & 3,8 & $-0,2$ \\
\hline & 20 & Pendataan jumlah dan jenis ikan & 4 & 3,8 & $-0,2$ \\
\hline & 21 & Keamanan TPI & 5 & 4,2 & 0,8 \\
\hline & 22 & Kejujuran dalam penarikan retribusi & 3,6 & 4,2 & $-0,6$ \\
\hline \multirow{4}{*}{ Pelayanan TPI } & 23 & Pelayanan TPI & 3,6 & 4 & $-0,4$ \\
\hline & 24 & Sikap pegawai TPI & 3,8 & 4 & $-0,2$ \\
\hline & 25 & Komunikasi dengan pihak pengelola & 3,2 & 4,2 & -1 \\
\hline & 26 & Pembinaan dan pengawasan & 4 & 4 & 0 \\
\hline \multirow{2}{*}{$\begin{array}{l}\text { Pelayanan } \\
\text { Koperasi }\end{array}$} & 27 & Pelayanan koperasi & 3,6 & 4 & $-0,4$ \\
\hline & 28 & Sikap pegawai koperasi & 3,4 & 4 & $-0,6$ \\
\hline
\end{tabular}

Sumber : Data primer diolahtahun 2017 
Hasil penilaian kinerja dan kepentingan terhadap nelayan pada Tabel 1 menempatkan masing-masing atribut ke dalam salah satu kuadran pada diagram kartesius tingkat kinerja dan kepentingan nelayan terhadap kegiatan pelelangan di TPI PPI Paotere. Berdasarkan gambar tersebut, diketahui bahwa garis yang membatasi kuadran adalah garis $\mathrm{X}=3,6$ yang merupakan nilai rata-rata tingkat kinerja dari atribut yang dianalisis dan garis $\mathrm{Y}=4,07$ yang merupakan nilai rata-rata tingkat kepentingan dari atribut yang dianalisis.

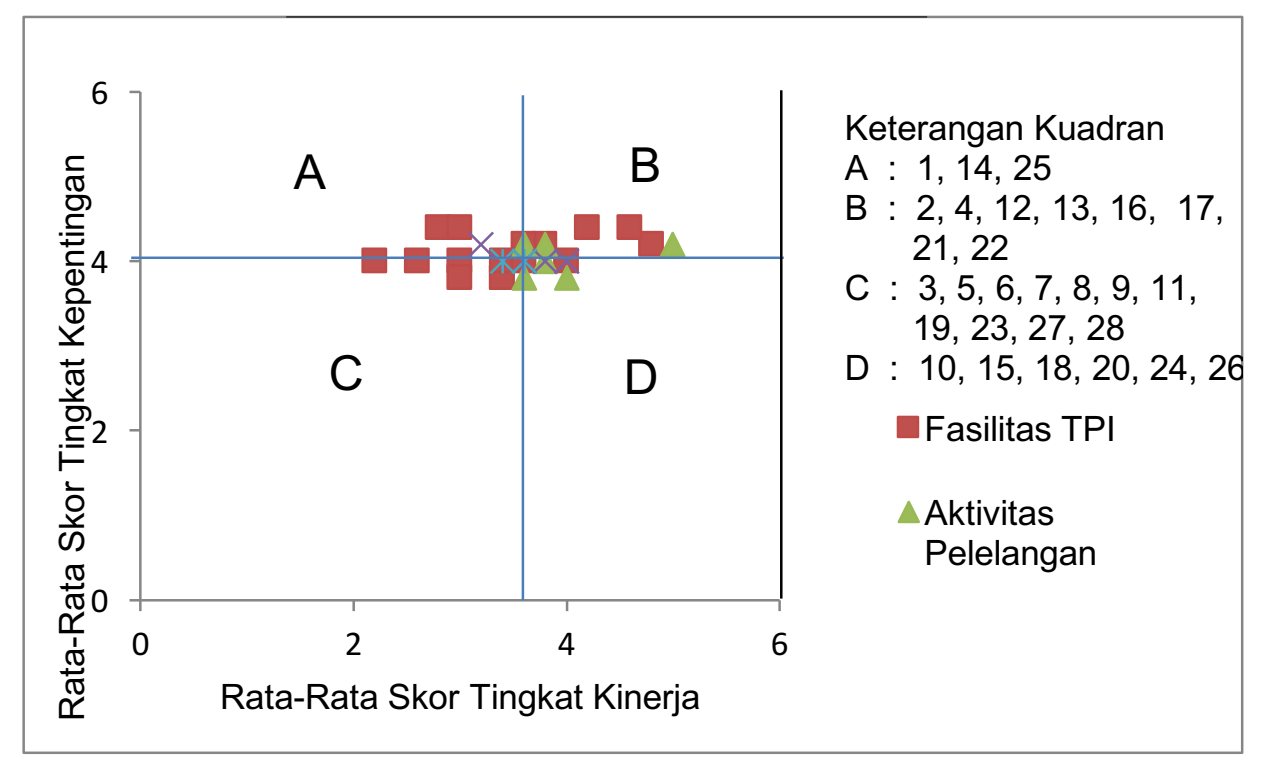

Gambar 1. Diagram kartesius tingkat kinerja dan kepentingan nelayan terhadap fasilitas, aktivitas dan pelayanan tempat pelelangan ikan (TPI) PPI Paotere

Atribut-atribut yang terdapat pada kuadran A merupakan atribut yang dianggap mempengaruhi kepuasan agen, termasuk unsur-unsur jasa yang dianggap sangat penting, namun manajemen belum melaksanakan sesuai keinginan pengguna pelelangan sehingga mengecewakan atau tidak memuaskan. Oleh sebab itu, pihak penyedia layanan harus meningkatkan pelayanan kinerjanya agar nelayan merasa puas. Atribut yang termasuk dalam kuadran ini adalah atribut nomor 1, 14 dan 25 yaitu kebersihan fasilitas TPI, akses masuk TPI, dan komunikasi dengan pihak pengelola.

Atribut-atribut yang terdapat pada kuadran B merupakan unsur jasa pokok yang telah berhasil dilaksanakan oleh pengelola tempat pelelangan ikan (TPI), sehingga wajib untuk dipertahankan. Atribut-atribut ini dianggap sangat penting dan sangat memuaskan. Atribut yang masuk dalam kuadran ini yaitu nomor 2, 4, 12, 13, 16, 17, 21 dan 22. Atribut ini terdiri dari perbaikan fasilitas TPI, basket, penyediaan es, penyediaan BBM, panjang dermaga, ketepatan waktu pelaksanaan lelang, keamanan TPI dan kejujuran dalam penarikan retribusi. 
Kuadran $\mathrm{C}$ menunjukkan faktor yang kurang penting pengaruhnya bagi pengguna pelelangan dan pelaksanaannya oleh pihak penyedia jasa biasa-biasa saja. Kuadran C merupakan kuadran yang menurut penggunanya dianggap kurang penting dan kurang memuaskan. Atribut-atribut yang terdapat dalam kuadran ini adalah atribut nomor 3, 5, 6, 7, 8, 9, 11, 19, 23, 27, 28 yaitu tempat kemudahan dalam penggunaan fasilitas, alat timbangan, gedung TPI, penyediaan air bersih, tempat cuci tangan dan toilet, cold storage, keadaan kantor administrasi, Administrasi di TPI, pelayanan TPI, pelayanan koperasi dan sikap pegawai koperasi.

Kuadran D merupakan faktor yang dianggap oleh pengguna pelelangan kurang penting akan tetapi pelaksanaannya berlebihan. Atribut yang termasuk ke dalam kuadran D yaitu nomor $10,15,18,20,24$ dan 26. Atribut yang termasuk dalam kuadran ini yaitu luas area TPI, ketersediaan lahan parkir, kemudahan dalam pembayaran, pendataan jumlah dan jenis ikan, sikap pegawai TPI, pembinaan dan pengawasan.

Berdasarkan diagram kartesius tingkat kinerja dan kepentingan nelayan terhadap fasilitas, aktivitas dan pealayan TPI PPI Paotere tersebut diketahui bahwa atribut terbagi menjadi kuadran A, B, C dan D. Pembagian atribut tiap kuadran tersebut dapat dilihat dengan jelas pada Tabel 2 .

Atribut-atribut yang dinilai kurang memuaskan oleh agen dan nelayan memiliki nilai kesenjangan yang berkisar antara $(-1,2-0,7)$. Atribut yang termasuk didalamnya adalah tempat cuci tangan dan toilet, komunikasi dengan pihak pengelola dan keadaan kantor administrasi. Atribut yang memiliki nilai kesenjangan berkisar antara $(-0,6--0,1)$ termasuk kedalam penilaian cukup puas oleh nelayan atau agen terhadap TPI. Atribut tersebut adalah perbaikan fasilitas TPI, kemudahan dalam penggunaan fasilitas, basket, alat timbangan, gedung TPI, ketepatan waktu pelaksanaan lelang, kemudahan dalam pembayaran, administrasi di TPI, pendataan jumlah dan jenis ikan, pelayanan TPI, sikap pegawai TPI, pelayanan koperasi, sikap pegawai koperasi, kejujuran dalam penarikan retribusi, luas area TPI dan penyediaan es. Atribut yang dinilai memuaskan oleh nelayan dan memiliki nilai kesenjangan antara $(0-0,5)$. Atribut yang termasuk didalamnya yaitu pembinaan dan pengawasan, ketersediaan lahan parkir dan panjang dermaga sedangkan atribut yang dinilai sangat memuaskan oleh nelayan dan memiliki nilai kesenjangan antara $(0,6-1,1)$. 
Tabel 2. Tingkat Kepuasan Nelayan

\begin{tabular}{c|c|l}
\hline $\begin{array}{c}\text { Selang frekuensi } \\
\text { Nilai kesenjangan }\end{array}$ & Tingkat Kepuasan & \multicolumn{1}{c}{ Atribut } \\
\hline$(-1,8--1,3)$ & Tidak Puas & $\begin{array}{l}\text { Kebersihan fasilitas TPI, Penyediaan air } \\
\text { bersih, Cold Storage dan Akses Masuk ke TPI }\end{array}$ \\
\hline$(-1,2--0,7)$ & Kurang Puas & $\begin{array}{l}\text { Tempat cuci tangan dan toilet, Komunikasi } \\
\text { dengan pihak pengelola dan Keadaan Kantor } \\
\text { Administrasi }\end{array}$ \\
\hline$(-0,6--0,1)$ & Cukup Puas & $\begin{array}{l}\text { Perbaikan fasilitas TPI, Kemudahan dalam } \\
\text { penggunaan fasilitas, Basket, Alat timbangan, } \\
\text { Gedung TPI, Ketepatan waktu pelaksanaan } \\
\text { lelang, Kemudahan dalam pembayaran, } \\
\text { Administrasi di TPI, Pendataan jumlah dan } \\
\text { jenis ikan, Pelayanan TPI, Sikap pegawai TPI, } \\
\text { Pelayanan koperasi, Sikap pegawai koperasi, } \\
\text { Kejujuran dalam penarikan retribusi, Luas } \\
\text { Area TPI dan Penyediaan Es }\end{array}$ \\
\hline$(0,0-0,5)$ & Puas & $\begin{array}{l}\text { Pembinaan dan pengawasan, Ketersediaan } \\
\text { Lahan Parkir dan Panjang Dermaga }\end{array}$ \\
\hline$(0,6-1,1)$ & Sangat Puas & Keamanan TPI dan Penyediaan BBM/Solar \\
\hline
\end{tabular}

Sumber : Data primer diolahtahun 2017

Berdasarkan Tabel 3 diketahui bahwa terdapat kesenjangan atau gap pada setiap atribut. Kesenjangan ini merupakan salah satu indikator tingkat kepuasan agen atau nelayan. Nilai kesenjangan (gap) yang didapat dari perhitungan selang frekuensi diketahui bahwa agen atau nelayan merasa cukup puas dengan pelayanan yang diberikan TPI baik dari fasilitas, aktivitas, pelayanan TPI serta pelayanan koperasi. Hal ini terlihat banyaknya kesenjangan yang masuk ke dalam selang $(-0,6--0,1)$. Nelayan menilai semua atribut yang terdapat di TPI sangat penting dan kinerja TPI saat ini dinilai cukup memuaskan.

Penilaian yang cukup memuaskan menurut nelayan tersebut memperlihatkan bahwa TPI harus meningkatkan kinerjanya sehingga para nelayan merasa lebih puas dengan pelayanan yang diberikan. TPI PPI Paotere harus meningkatkan pelayanan dalam penyediaan fasilitas, meningkatkan aktivitas pelelangan, meningkatkan pelayanan baik dari TPI sendiri dan koperasi yang mengurusi semua kegiatan di tempat pelelangan ikan tersebut

\section{Kepuasan Pedagang}

Hasil penilaian kinerja dan kepentingan terhadap pedagang menempatkan masingmasing atribut ke dalam salah satu kuadran pada diagram kartesius tingkat kinerja dan kepentingan nelayan terhadap kegiatan pelelangan di TPI PPI Paotere. Berdasarkan gambar tersebut, diketahui bahwa garis yang membatasi kuadran adalah garis $\mathrm{X}=3,9$ yang merupakan 
nilai rata-rata tingkat kinerja dari atribut yang dianalisis dan garis $Y=4,12$ yang merupakan nilai rata-rata tingkat kepentingan dari atribut yang dianalisis.

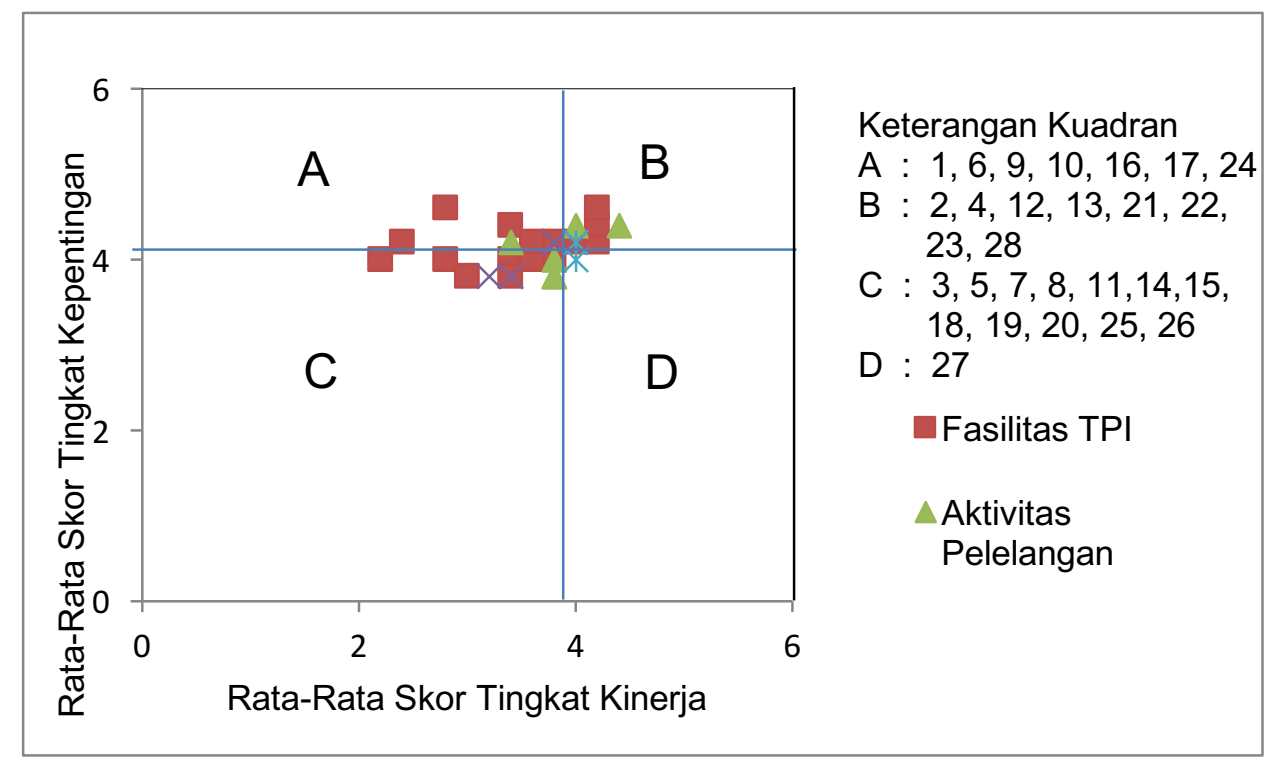

Gambar 2. Diagram kartesius tingkat kinerja dan kepentingan pedagang terhadap fasilitas, aktivitas dan pelayanan tempat pelelangan ikan (TPI) PPI Paotere

Berdasarkan diagram kartesius tingkat kinerja dan kepentingan pedagang terhadap fasilitas, aktivitas dan pelayanan TPI PPI Paotere diketahui bahwa atribut terbagi menjadi kuadran A, B, C dan D.Atribut-atribut yang terdapat pada kuadran A merupakan atribut yang dianggap mempengaruhi kepuasan agen, termasuk unsur-unsur jasa yang dianggap sangat penting, namun manajemen belum melaksanakan sesuai keinginan pengguna pelelangan sehingga mengecewakan atau tidak memuaskan. Oleh sebab itu, pihak penyedia layanan harus meningkatkan pelayanan kinerjanya agar nelayan merasa puas. Atribut yang termasuk dalam kuadran ini adalah atribut nomor 1, 6, 9, 10, 16, 17 dan 24 yaitu kebersihan fasilitas TPI, gedung TPI, old storage, ketepatan waktu pelaksanaan lelang, pelayanan koperasi, sikap pegawai koperasi dan penyediaan es.

Atribut-atribut yang terdapat pada kuadran B merupakan unsur jasa pokok yang telah berhasil dilaksanakan oleh pengelola tempat pelelangan ikan (TPI), sehingga wajib untuk dipertahankan. Atribut-atribut ini dianggap sangat penting dan sangat memuaskan. Atribut yang masuk dalam kuadran ini yaitu nomor 2, 4, 12, 13, 21, 22, 23 dan 28. Atribut ini terdiri dari perbaikan fasilitas TPI, basket, administrasi TPI, pendataan jumlah dan jenis ikan, pembinaan dan pengawasan, luas area TPI, keadaan kantor administrasi dan panjang dermaga.

Kuadran $\mathrm{C}$ menunjukkan faktor yang kurang penting pengaruhnya bagi pengguna pelelangan dan pelaksanaannya oleh pihak penyedia jasa biasa-biasa saja. Kuadran C merupakan kuadran yang menurut penggunanya dianggap kurang penting dan kurang 
memuaskan. Atribut-atribut yang terdapat dalam kuadran ini adalah atribut nomor 3, 5, 7, 8, $11,14,15,18,19,20,25,26$ yaitu tempat kemudahan dalam penggunaan fasilitas, alat timbangan, penyediaan air bersih, tempat cuci tangan dan toilet, kemudahan dalam pembayaran, pelayanan TPI, sikap pegawai TPI, komunikasi dengan pihak pengelola, penyediaan BBM dan akses masuk TPI.

Kuadran D merupakan faktor yang dianggap oleh pengguna pelelangan kurang penting akan tetapi pelaksanaannya berlebihan. Atribut yang termasuk ke dalam kuadran D yaitu ketersediaan lahan parkir. Nilai kesenjangan dari berbagai atribut tersebut digolongkan atas 5 tingkatan yaitu tidak puas, kurang puas, cukup puas, puas dan sangat puas. Penentuan tingkat kepuasan ini dilakukan berdasarkan skala tertentu yang diperoleh melalui penentuan selang frekuensi/kelas tiap atribut. Berdasarkan nilai kesenjangan, dapat diketahui bahwa kepuasan pedagang yang memiliki nilai kesenjangan antara $(-1,8--1,4)$ termasuk kepada penilaian tidak puas terhadap atribut yang terdapat di TPI. Atribut tersebut adalah kebersihan fasilitas TPI, cold storage dan akses masuk ke TPI. Atribut-atribut yang dinilai kurang memuaskan oleh pedagang memiliki nilai kesenjangan yang berkisar antara $(-1,3-0,9)$. Atribut yang termasuk di dalamnya adalah gedung TPI dan penyediaan air bersih.

Berdasarkan hasil analisis data diketahui bahwa terdapat kesenjangan atau gap pada setiap atribut. Kesenjangan ini merupakan salah satu indikator tingkat kepuasan pedagang. Nilai kesenjangan (gap) yang didapat dari perhitungan selang frekuensi diketahui bahwa pedagang merasa cukup puas dengan pelayanan yang diberikan TPI baik dari fasilitas, aktivitas, pelayanan TPI serta pelayanan koperasi. Hal ini terlihat dari banyaknya kesenjangan (gap) yang masuk kedalam selang $(-0,8--0,4)$. Nelayan menilai bahwa semua atribut yang terdapat di TPI sangat penting dan kinerja TPI yang ada saat ini dinilai cukup memuaskan. Penilaian yang cukup memuaskan menurut pedagang tersebut memperlihatkan bahwa TPI harus meningkatkan kinerjanya sehingga para nelayan merasa lebih puas dengan pelayanan yang diberikan. TPI PPI Paotere harus meningkatkan pelayanan dalam penyediaan fasilitas, meningkatkan aktivitas pelelangan, meningkatkan pelayanan baik dari TPI sendiri dan koperasi yang mengurusi semua kegiatan di tempat pelelangan ikan tersebut.

Perbandingan tingkat kepuasan dari nelayan dan pedagang tidak berbeda jauh. Hal ini terbukti dengan banyaknya atribut yang berada pada interval kategori cukup puas baik itu dari persepsi nelayan maupun dari pedagang. Untuk tingkat kepuasan nelayan untuk kategori tidak puas ada 4 atribut, kategori kurang puas ada 3 atribut, kategori cukup puas ada 16 atribut, kategori puas ada 3 atribut, dan kategori sangat puas ada 2 atribut. Sedangkan untuk tingkat kepuasan pedagang untuk kategori tidak puas ada 3 atribut, kategori kurang puas ada 2 atribut, 
kategori cukup puas ada 12 atribut, kategori puas ada 11 atribut, dan pada kategori sangat puas tidak ada atribut.

\section{Indikator kinerja tempat pelelangan ikan}

Pengukuran kinerja TPI Paotere menggunakan beberapa indikator kinerja yaitu input dan output. Indikator tersebut akan menentukan nilai kinerja dari segi ekonomis dan efisiensi pengelolaan tempat pelelangan ikan

\section{Indikator kinerja input}

\section{a. Sumberdaya manusia (SDM)}

Sumberdaya manusia merupakan salah satu indikator kinerja input karena manusia mengelola suatu tempat agar dapat berjalan sesuai dengan fungsi dan peranannya. Sumberdaya manusia yang mengelola tempat pelelangan ikan PPI Paotere berjumlah 33 orang. Jumlah ini merupakan gabungan antara pegawai negeri sipil (PNS), pegawai tenaga kontrak dan pegawai tenaga sukarela.

Berdasarkan hasil wawancara dengan Kepala TPI Paotere, personil TPI yang ditempatkan untuk mengelola TPI ini dianggap belum ideal, sehingga diperlukan penambahan jumlah pegawai sekitar 10 orang untuk mengelola tempat pelelangan ikan dengan baik. Terutama untuk jumlah pegawai kebersihan masih dianggap kurang, sedangkan frekuensi pelelangan di TPI Paotere dilakukan dua kali dalam sehari.

\section{b. Luas lantai lelang}

Lantai lelang merupakan salah satu fasilitas penting yang harus ada pada suatu tempat pelelangan ikan. Luas lantai lelang berhubungan erat dengan volume produksi hasil tangkapan yang dapat ditampung oleh tempat pelelangan ikan.

Menurut data UPTD PPI Paotere luas lantai lelang TPI Paotere sebesar $1.176 \mathrm{~m}^{2}(49 \mathrm{x}$ $24 \mathrm{~m}^{2}$ ). Luas lantai lelang ini masih kurang, karena banyak penjual yang masih menggunakan aktivitas bukan di lantai lelang, tapi di jalan sekitar dermaga. Luas lantai jalan yang dipergunakan ada sekitar $\pm 196 \mathrm{~m}^{2}$.

\section{c. Volume produksi}

Volume produksi merupakan bagian penting yang harus diketahui dalam suatu kegiatan pelelangan karena volume produksi merupakan bahan baku yang akan diperjualbelikan di tempat pelelangan ikan. Volume produksi pada tahun 2014 yaitu 7.393 ton sedangkan nilai ratarata volume produksi 4 tahun sebelumnya yaitu antara tahun 2010-2013 didapatkan jumlah 
volume produksi sebesar 7.110,625 ton. Perhitungan rata-rata volume produksi dapat dilihat pada Lampiran 3.

\section{Indikator kinerja output}

Output merupakan hasil dari suatu input setelah mengalami sebuah proses. Indikator kinerja output TPI Paotere terbagi menjadi tiga, yaitu:

\section{a. Nilai produksi}

Nilai Produksi TPI Paaotere pada tahun 2014 yaitu sebesar Rp 173.735.500.000, sedangkan untuk rata-rata nilai produksi dua tahun sebelumnya yaitu tahun 2012-2013 sebesar Rp 130.198.203.750. Untuk perhitungan matematis rata-rata nilai produksi dapat dilihat pada lampiran 3

\section{b. Pendapatan Pemerintah Daerah}

Pemerintah Daerah merupakan salah satu lembaga pemerintah yang mendapatkan hasil retribusi dari proses pelelangan yang terjadi di tempat pelelangan ikan (TPI). Hasil retribusi yang masuk ke Pemerintah Daerah akan menjadi pemasukan bagi kas daerah yang akan digunakan kembali untuk kesejahteraan masyarakat pada daerah tersebut.

Pendapatan yang diterima Pemerintah Daerah Kota pada tahun 2014 yaitu sebesar Rp. 868.568.000, sedangkan target pemerintah untuk retribusi tempat pelelangan ikan di TPI Paotere pada tahun 2014 yaitu sebesar Rp 859.124.800.

\section{d. Kepuasan pengguna pelelangan}

Kepuasan dikategorikan sebagai tujuan tingkat tinggi dalam suatu sistem pengukuran kinerja. Oleh sebab itu, pembuatan indikator kinerja harus memasukkan indikator kepuasan pengguna pelelangan. Menurut jenisnya, kepuasan pengguna pelelangan terbagi menjadi dua yaitu kepuasan nelayan dan kepuasan pedagang, sedangkan menurut atribut pengukuran kepuasan yang dilakukan di TPI PPI Paotere terbagi menjadi 4 yaitu fasilitas TPI, aktifitas pelelangan, pelayanan TPI dan pelayanan koperasi.

Indikator kinerja dapat dihitung dengan menggunakan rumus matematis yaitu perbandingan antara capaian (realisasi) dengan target kinerja (rencana). Rencana merupakan standar yang seharusnya dimiliki oleh sebuah lembaga atau pada awal pembangunan lembaga tersebut sudah memilikinya, sedangkan realisasi merupakan hasil yang telah tercapai oleh lembaga tersebut pada saat ini baik dari segi input dan output 


\section{Input}

Rataan input sebesar 86\% menunjukkan bahwa kinerja yang dimiliki TPI dari segi input belum optimal. Hal ini disebabkan terdapat beberapa indikator kinerja kurang dari target (standar indikator) dan beberapa indikator kinerja yang melebihi target. Nilai kinerja yang kurang dari 100\% mengindikasikan bahwa SDM yang ada saat ini kurang dari standar indikator yang seharusnya. Sumberdaya manusia yang kurang dari target tersebut akan membuat pegawai melakukan tugas ganda. Jumlah pekerjaan yang seharusnya dikerjakan tidak sesuai dengan jumlah karyawan yang ada

\section{Output}

Nilai rataan indikator kinerja output sebesar 106\%. Nilai ini menunjukkan bahwa beberapa indikator output seperti pendapatan nelayan dan pendapatan Pemerintah Daerah lebih tinggi dibandingkan target. Nilai Produksi dan pendapatan Pemerintah Daerah mengalami peningkatan dibandingkan dengan tahun sebelumnya. Hal ini menunjukkan bahwa hasil yang didapatkan dari proses pelelangan cukup optimal. Nilai kinerja untuk nilai produksi dan pemasukan daerah masing-masing sebesar $133 \%$ dan 101\%. Nilai kinerja ini di atas $100 \%$. Hal ini menunjukkan bahwa proses pelelangan yang terjadi memberikan peningkatan pendapatan nelayan dan Pemerintah Daerah setiap tahunnya.

\section{Simpulan}

Kesimpulan dari penelitian ini adalah sebagai berikut :

Aktivitas pelaksanaan pelelangan tempat pelelangan ikan di TPI Paotere dikelola oleh pihak TPI yang bertugas untuk mengatur dan mengawasi jalannya aktivitas pelelangan dan dibantu oleh pihak koperasi.

Kepuasan pengguna pelelangan di TPI PPI Paotere secara keseluruhan masih dibawah kriteria puas karena dianggap belum memberikan pelayanan yang optimal bagi pengguna pelelangan. Kriteria tersebut adalah cukup puas bagi nelayan terhadap pelayanan yang diberikan. Hal yang sama juga bagi pedagang menganggap cukup puas terhadap pelayanan yang diberikan.

Kinerja tempat pelelangan ikan di PPI Paotere secara keseluruhan dinilai cukup ekonomis dari segi input karena memiliki nilai kinerja input sebesar $86 \%$, sedangkan kinerja pengelolaan TPI dinilai tidak efisien dengan nilai kinerja 123\%. 


\section{Daftar Pustaka}

Departeman Perikanan dan Kelautan, 2004. PengembanganPrasaranaPerikanan. Jakarta. 269 hal.

Direktorat Jenderal Perikanan, 1994. Pengembangan dan Pengelolaan Prasarana Pelabuhan Perikanan. 49 hal.

Iqbal, M. 2015. Strategi Pengembangan Pangkalan Pendaratan Ikan (PPI) PaotereMakassar [Skripsi]. Makassar :FakultasPerikanandanIlmuKelautan, UniversitasHasanuddin.

Kimursih. 2010. Pengkajian Upaya Peningkatan Kebersihan di Lingkungan Tempat Pelelangan Ikan Pelabuhan Perikanan Nusantara Palabuhan Ratu Sukabumi [Skripsi]. Bogor: Fakultas Perikanan dan Ilmu Kelautan, Institut Pertanian Bogor.

Lubis, E. 2010. PelabuhanPerikanan. Bogor (ID): IPB Press

Mahmudi. 2010. Manajemen Kinerja Sektor Publik, Edisi Kedua. Yogyakarta: Unit Penerbit dan Percetakan Sekolah Tinggi Ilmu Manajemen YKPN.

Panggabean. 2008. Tingkat Kepuasan Nelayan Terhadap Pelayanan Penyediaan Kebutuhan Melaut di PPN Sibolga Sumatera Utara. [Skripsi]. Bogor (ID): Fakultas Perikanan dan Ilmu Kelautan, Institut Pertanian Bogor

R. Nugroho Purwantoro.2004. Efektifitas Kinerja Pelabuhan dengan Data Envelopment Analysis. Usahawan No 05 Th.XXXIII. Mei 2004.

Resti, DewiFifi. 2012. Pengukuran Kinerja Pengelolaan Tempat Pelelangan Ikan Di PPI MuaraAngke. Bogor: Fakultas Perikanan dan Ilmu Kelautan, Institut Pertanian Bogor.

UPTD PPI Paotere. 2014. Laporan Monitoring PPI Paotere. Makassar: UPTD PPI Paotere.

Widayati T. 2008. Analisis Efisiensi Teknis Tempat Pelelangan Ikan dan Tingkat Keberdayaan Pengelola Tempat Pelelangan Ikan Serta Strategi Pemberdayaannya di Wilayah Pantai Utara Jawa Tengah [Tesis]. Semarang: Program Pascasarjana, UniversitasDipenogoro Semarang.

Widiastuti A. 2010. Kinerja Operasional Pelabuhan Perikanan Samudera Nizam Zachman Jakarta [Skripsi]. Bogor: Fakultas Perikanan dan Ilmu Kelautan, Institut Pertanian Bogor. 